\title{
MODEL PENDEKATAN CENTRE BASED DALAM MENANGANI ANAK JALANAN PEREMPUAN
}

\section{Oleh:}

\author{
Rivanlee Anandar ${ }^{1}$, Hery Wibowo. ${ }^{2}$, \\ ${ }^{1}$ Mahasiswa Program Studi Kesejahteraan Sosial (170310120068), Fakultas Ilmu Sosial dan Ilmu \\ Politik, Universitas Padjadjaran (Penulis) \\ ${ }^{2}$ Dosen Program Studi Kesejahteraan Sosial, Fakultas Ilmu Sosial dan Ilmu Politik, Universitas \\ Padjadjaran (Pembimbing Kajian Artikel)
}

E-mail: rivanlee@gmail.com; hery_fortune@yahoo.com

\begin{abstract}
ABSTRAK
Keberadaan anak-anak jalanan di berbagai sudut jalan adalah konsekuensi logis bagi Bandung sebagai kota metropolitan. Anak jalanan dipandang sebagai masalah yang memberi citra kurang baik terhadap pembangunan. Selain menambah beban pembangunan, persoalan anak jalanan-terutama perempuan-menjadi kian rumit ketika mereka menjadi sasaran empuk perdagangan manusia atau pekerja seks.

Hal ini disebabkan mereka tidak terlindungi dengan semestinya dan pengetahuan yang mereka miliki sangatlah minim. Anak jalanan perempuan bahkan menanggung resiko jauh lebih berat ketimbang anak jalanan laki-laki. Untuk menghindari anak jalanan perempuan menjadi sasaran eksploitasi atau orientasi seksual bebas lelaki, perlu adanya pendampingan khusus bagi anak jalanan perempuan. Saat ini, Proses pendidikan tersebut dapat dilakukan melalui penanganan di lembaga/pusat pelayanan. Lembaga dengan penanganan model semacam ini adalah rumah singgah.

Rumah singgah dianggap bisa memberikan pendidikan serta pemahaman bagi anak-anak jalanan perempuan untuk dapat mengubah sikap dan cara pandangnya melihat kehidupan. Berangkat dari masalah ini, saya berinisiatif untuk menawarkan ide rumah singgah khusus anak jalanan perempuan.
\end{abstract}

Kata Kunci : Rumah Singgah, Anak Jalanan, Perempuan

\begin{abstract}
The existence of street children in various corners of the street is a logical consequence for Bandung as a metropolitan city. Street children are seen as a problem that gives poor image of the development. Besides adding to the burden of development, the issue of street children-especially girls-become even more complicated when they become easy targets of human trafficking or sex workers.

This is because they are not protected properly and the knowledge they have severely limited. Street children women bear the risk of even much greater than the male street children. To avoid the street children of women subjected to exploitation or sexual orientation free man, the need for special assistance for street children women. Currently, the education process can be done through handling in the institution / service center. Institutions with handling this kind of model is a halfway house.

Shelters should be able to provide education and understanding for female street children to be able to change the attitude and outlook look at life. Departing from this problem, I took the initiative to offer the idea of a halfway house specifically female street children.
\end{abstract}

Keywords: guest house, street child, women 


\section{PENDAHULUAN}

Perkembangan pesat anak-anak jalanan di berbagai sudut jalan adalah konsekuensi logis bagi Jakarta sebagai kota metropolitan. Anak jalanan di perkotaan akan memberikan kesan kota itu kumuh. Anak jalanan dipandang sebagai masalah yang memberi citra kurang baik terhadap pembangunan. pasalnya, keberadaan anak jalanan kerap dijadikan cerminan dari perkotaan tersebut perihal krisis nilai sosial. Childhope-Asia (1993) menuliskan bahwa fenomena anak jalanan merupakan indikator utama terhadap adanya kemelaratan perkotaan dan krisis nilai-nilai sosial yang menghadang negara-negara di wilayah itu.

Selain itu, Andari (2006:18) mengatakan penyebab anak turun ke jalan antara lain, stress yang dialami orang tua, rendahnya kemampuan dalam pengasuhan dan perawatan anak, kekerasan dalam keluarga; rendahnya tingkat kemampuan ekonomi keluarga yang mengakibatkan tidak mampunya keluarga memenuhi kebutuhan anak.

Ketidakmampuan orang tua menghidupi anak-anaknya itulah yang turut mendorong anak turun ke jalan. Anak-anak perempuan jalanan yang terlibat dalam dunia prostitusi tak jarang mendapat tindakan kekerasan seksual dari beberapa pihak seperti germo yang sering dianggap sebagai kiwirkiwir (istilah untuk status pacar), pelanggan, sampai aparat keamanan. Pada beberapa peristiwa yang terlapor, anak-anak jalanan perempuan seringkali mendapat peristiwa buruk seperti, perkosaan keroyokan, aksi seksual tidak wajar misalnya dengan menggunakan alat-alat, atau hubungan yang tidak menggunakan kondom. (Umrah, 2015:49)

Anak sebagai perempuan mempunyai situasi yang rentan untuk mengalami kekerasan dan diskriminasi dimanapun mereka berada apakah di wilayah domestik maupun publik. Pengalaman pahit yang terjadi pada anak jalanan perempuan ini tentu memberi dampak buruk seperti tertular penyaki menular seksual, gonorrhea, syphilis, condo loma, dan herpes simplex. Terlebih lagi, ada yang terjerat narkotika dan zat adiktif. (Umrah, 2015:51).

Beragamnya masalah yang muncul di jalanan terhadap anak jalanan, tetap saja menjadi tanggung jawab bagi pemerintah untuk melindungi mereka. Anak jalanan wajib mendapatkan perlindungan dan diarahkan melalui proses pendidikan untuk benar-benar keluar dari lingkungan tersebut. UndangUndang Perlindungan Anak yang disahkan oleh pemerintah sebagai perwujudan untuk melaksanakan pemenuhan, pemajuan, perlindungan hak anak bagi seluruh anak Indonesia berlaku bagi semua jenis kelamin, status sosial, agama, ras dan etnis. (Sitorus, 2015:8)

Anak jalanan yang berada di jalanan harus mendapat perlindungan yang sama sebagaimana anak. Seperti yang tertulis di dalam UU Perlindungan Anak No. 23 tahun 2002 dinyatakan bahwa setiap anak dengan prinsip nondiskriminatif harus diakui hak sipil dan kebebasannya, pendidikan, kesehatan, dan pengasuhan. Proses tersebut dapat dilakukan melalui penanganan di lembaga/pusat pelayanan. Lembaga dengan penanganan model semacam ini adalah rumah singgah.

Rumah singgah adalah suatu wahana yang dipersiapkan sebagai perantara antara anak jalanan dan pihak-pihak yang membantu mereka (Modul Pelatihan Pimpinan Rumah Singgah, 2000:96). Berdasarkan pengertian tersebut rumah singgah merupakan proses informal yang memberikan suasana sosial kepada anak jalanan terhadap sistem nilai dan norma yang berlaku di masyarakat setempat. 
Secara umum, tujuan dibentuknya rumah singgah adalah membantu anak jalanan dalam mengatasi masalah-masalah dan menemukan alternatif untuk pemenuhan kebutuhan hidupnya.

Kemudian dilanjutkan dengan tahap residential shelter di mana anak tinggal menetap dan hidup di tempat tersebut sebagai rumah tinggal mereka. Pentingnya menerapkan pendekatan centre based dalam menangani anak jalanan karena rogram centre based terbagi menjadi dua tahap, tahap drop in shelter sebagai tahap awal di mana anak masih diperbolehkan kembali ke jalan karena masih beradaptasi dari lingkungan jalanan ke lingkungan rumah (Anastia 2002:23). program centre based ialah upaya pendekatan yang diterapkan lembaga dalam menjangkau anak jalanan melalui pengadaan program dan pelayanan dengan cara pemberian dukungan pada kesejahteraan dan perkembangan anak.

Maka penting kiranya dilakukan kajian khusus tentang anak jalanan ini untuk mendapatkan bahasan lebih mendalam tentang fenomena ini sekaligus beragam alternatif pemikiran terkait upaya penanganannya

\section{TINJAUAN TEORITIS}

Departemen Sosial RI dalam Fery Johanes (2007) "Penanganan Anak Jalanan di Indonesia" mendefinisikan anak jalanan sebagai anak yang menggunakan sebagian waktunya dijalanan baik untuk bekerja maupun tidak yang terdiri dari anak-anak yang masih mempunyai hubungan dengan keluarga atau sudah putus hubungan dengan keluarga dan anak-anak yang hidup mandiri sejak masa kecil karena kehilangan keluarga atau orang tuanya. Mereka kerap kali menghabiskan waktunya untuk bekerja, entah untuk kebutuhan pribadi entah untuk membantu keluarganya. Pekerjaan yang biasa dilakukan anak jalanan sangat beragam. Mulai dari berjualan tisu, menyediakan jasa menyemir sepatu, sampai mengemis. Kebanyakan dari anak jalanan dapat ditemukan di persimpangan jalan karena terdapat lampu merah tempat kendaraan berhenti, tapi ada juga yang bergerak di pasar tradisional dan jembatan. UNICEF memberikan pengertian tentang anak jalanan sebagai berikut:

"Anak jalanan merupakan anak-anak
yang berumur di bawah 16 tahun yang
sudah melepaskan diri dari keluarga,
sekolah, dan lingkungan masyarakat
terdekatnya, larut dalam kehidupan
yang berpindah-pindah di jalan raya."
Di Indonesia, batasan mengenai anak jalanan pun beragam. Direktorat Bina Sosial DKI dalam Laporan Penelitian Anak Jalanan (1989: 5) mengatakan bahwa yang termasuk anak jalanan adalah anak yang berkeliaran di jalan raya sambil bekerja, mengemis, atau menganggur saja. Usianya berkisar dari bayi (yang dibawa orang tuanya mengemis) hingga remaja.

Anak jalanan yang bekerja dan mencari uang di jalanan terbagi ke dalam tiga tipologi atau kelompok, seperti yang dikemukakan oleh Sri S. Hariadi dan Suyanto (1999: 78-82), yaitu:

\section{Children on the Street}

Anak yang bekerja di jalan merupakan mereka yang menghabiskan sebagian besar waktunya di jalanan atau di tempat umum lainnya untuk bekerja dan penghasilannya digunakan untuk membantu keluarganya. Anak-anak tersebut mempunyai kegiatan ekonomi (sebagai pekerja anak) di jalan dan masih mempunyai hubungan yang kuat dengan orang tua mereka.

2. Children of the street

Anak-anak yang hidup di jalan merupakan mereka yang menghabiskan sebaian besar waktunya di jalan atau ditempat umum 
lainnya, tetapi hanya sedikit yang digunakan untuk bekerja. Mereka jarang berhubungan dengan keluarganya. Beberapa di antara mereka hidup di sembarang tempat dan tidak memiliki rumah tinggal. Banyak di antara mereka adalah anak-anak yang karena suatu sebab lari atau pergi dari rumah. Anak-anak seperti ini rawan terhadap perilaku menyimpang, baik emosional, fisik maupun seksual.

\section{Children in the Street}

Merupakan anak-anak yang menghabiskan seluruh waktunya di jalanan yang berasal dari keluarga yang hidup atau tinggalnya juga di jalanan.

\section{Pemberdayaan Anak Jalanan}

Secara konseptual, pemberdayaan atau pemberkuasaan (empowerment), berasal dari kata power (kekuasaan atau keberdayaan). Oleh karena itu, ide utama pemberdayaan bersentuhan dengan konsep mengenai kekuasaan. Kekuasaan seringkali dikaitkan dengan kemampuan kita untuk membuat orang lain melakukan apa yang kita inginkan, terlepas dari keinginan dan minat mereka.

Konsep pemberdayaan adalah salah satu konsep utama dalam Ilmu Kesejahteraan Sosial pada era 1990-an hingga sekarang dan seringkali pemberdayaan dikaitkan dengan intervensi komunitas atau kelompok. Menurut Soetrisno dikutip oleh Usman (2000:185) dalam tulisannya mengemukakan bahwa paradigma pemberdayaan ingin mengubah kondisi dengan cara memberi kesempatan kepada kelompok orang miskin untuk merencanakan dan kemudian melaksanakan program pembangunan yang juga merupakan pilihan mereka sendiri.

Pemberdayaan menekankan bahwa
orang memperoleh pengetahuan, dan kekuasaan yang cukup untuk mempengaruhi kehidupannya dan kehidupan orang lain yang menjadi perhatiannya. Sedangkan menurut Payne (1997:266) dikutip oleh Adi (2001:32) bahwa suatu proses pemberdayaan, pada intinya ditujukan untuk:

"Membantu klien memperoleh daya untuk mengambil keputusan dan menentukan tindakan yang akan ia lakukan yang terkait dengan diri mereka, termasuk mengurangi efek hambatan pribadi dan sosial dalam melakukan tidakan. Hal ini dilakukan melalui peningkatan kemampuan dan rasa percaya diri untuk menggunakan daya yang ia miliki, antara lain melalui transfer daya dari lingkungannya."

Berdasarkan pengertian di atas, pemberdayaan memiliki tujuan untuk mengubah melalui penguasaan terhadap sesuatu yang nanti disumbangkan pada program-program yang berkaitan. Pada tulisan ini, anak jalanan yang menjadi sasaran dari pemberdayaan tersebut. Konsep pemberdayaan secara langsung memiliki tujuan yaitu keberpihakan dan kepedulian dalam mengurangi anak-anak turun ke jalan dan membuat mereka untuk berdaya agar memiliki semangat bekerja untuk membangun diri mereka sendiri.

\section{Prinsip Pemberdayaan}

Brenda dan Miley (1992 : 212) dalam Maria (2001:58) mengemukakan tentang prinsip-prinsip dan asumsi-asumsi pemberdayaan dalam pekerjaan sosial sebagai berikut:

1) Pemberdayaan merupakan sebuah kolaborasi proses antara masyarakat yang diberdayakan dengan lembaga pemberdaya.

2) Proses pemberdayaan memandang sistem klien merupakan sesuatu yang penting dan mampu, memberikan kesempatan bahkan untuk mengakses berbagai sumber. 
3) Klien harus mempersepsikan dirinya sebagai agen penyebab yang bisa membawa perubahan.

4) Kecakapan atau kesopanan diperoleh melalui pengalaman dalam kehidupan, khususnya mengenai pengalaman keberhasilan dari pada keadaan dimana seseorang menyatakan apa yang dikerjakan.

5) Solusi itu muncul dan situasi perlu menekankan pada berbagai faktor yang cukup beragam di dalam situasi masalah tersebut.

6) Berbagai jaringan kerja sosial secara informal merupakan suatu dukungan sumber yang penting untuk memfasilitasi tekanan stress dan meningkatkan kemampuan seseorang serta meningkatkan kontrol.

7) Seseorang harus berpartisipasi di dalam memberdayakan dirinya sendiri, tujuan alat dan hasil yang diperoleh harus didefinisikannya sendiri.

8) Tingkat kesadaran adalah kunci pokok persoalan dalam pemberdayaan, memobilisasi pengetahuan untuk mengadakan perubahan.

9) Pemberdayaan melibatkan penjangkauan berbagai sumber dan kemampuan untuk menggunakan sumber-sumber terebut secara efektif.

10) Pemberdayaan adalah suatu proses yang dinamis, berkeinambungan, selalu berubahan dan berjalan secara evolusi, pemecahan masalah selalu mempunyai tingkatan pemecahan tertentu.

11) Pemberdayaan diperoleh melaui struktur personal dan pengembangan sosial ekonomi yang paralel

Sebuah pemberdayaan merupakan hasil kolaborasi antara pekerja sosial dengan klien. Di satu sisi, pekerja sosial harus meyakini bahwa anak jalanan adalah orang yang mampu mengubah dirinya sendiri. Dari situ, pekerja sosial dapat melakukan tindakan lebih lanjut yaitu, penyadaran. Penyadaran berarti bahwa anak jalanan secara keseluruhan menjadi sadar bahwa mereka mempunyai tujuan-tujuan dan masalah-masalah. Anak jalanan yang sadar juga mulai menemukan peluang-peluang dan

memanfaatkannya, menemukan sumberdayasumberdaya yang dapat membuat keberfungsian sosialnya kembali hidup.

$$
\text { Maka upaya pemberdayaan }
$$
merupakan upaya kolaboratif antara klien dan pekerja sosial untuk membuat keberfungsian klien lebih baik. Pada konteks anak, pemberdayaan adalah upaya mereka lebih berdaya/berkuasa, lebih terpenuhi haknya dan memiliki akses terhadap pemenuhan kebutuhannya.

\section{Strategi Pemberdayaan}

Pada tahun 1981, Longres mengadakan pengamatan tentang strategi intervensi dan program yang bertujuan untuk menangani masalah sosial. dalam penanganan masalah sosial ini, Longres menghubungkan antara asumsi dan ideologi yang membentuk masalah tersebut, serta menjadi norma dasar dilakukannya intervensi. Yang kemudian dikembangkan lebih lanjut oleh Lusk pada tahun 1984. Strategi yang dibuat Longres berawal dari adaptasi sistem sosial hingga kebutuhan individu, dari adaptasi individu hingga prasyarat sistem sosial. dengan demikian pengembangan program strategi intervensi bagi anak jalanan tersebut meliputi (Lusk, 1984:65):

a. Pendekatan Koreksional

Anak jalanan dalam pandangan ini didominasi oleh pemikiran bahwa anak jalanan banyak yang berurusan dengan dunia kriminal. Oleh karena itu, intervensi yang cocok adalah memindahkan anak dari jalanan dan memperbaiki perilaku mereka. Pendekatan ini fokus pada mendidik kembali agar sesuai dengan norma yang berlaku di masyarakat. 
b. Pendekatan Rehabilitasi

Anak jalanan dilihat sebagai anak yang dirugikan oleh lingkungannya, sehingga mengakibatkan banyak program-program sukarela muncul. Pendekatan rehabilitatif memandang anak jalanan sebagai anak yang berada dalam kondisi ketidakmampuan, membutuhkan, ditelantarkan, dirugikan, sehingga intervensi yang dilakukan adalah dengan melindungi dan merehabilitasi.

c. Pendekatan yang dilakukan di Jalanan Pendekatan ini mengasumsikan bahwa hal terbaik untuk menanggulangi masalah anak jalanan adalah dengan mendidik dan memberdayakan anak jalanan. Para pendidik jalanan yakin kesenjangan struktur sosial merupakan penyebab dari masalah ini. Dengan melibatkan partisipasi dari anak jalanan itu sendiri maka dapat dipelajari tentang situasi mereka dan mengikutsertakan dalam aksi bersama guna menemukan pemecahan dari masalah bersama.

d. Pencegahan

Pendekatan ini memandang penyebab dari masalah anak jalanan adalah dorongan masyarakat itu sendiri. strategi pencegahan berusaha memberikan pendidikan dan advokasi serta mencoba menemukan penyelesaian dari apa yang diperkirakan menjadi penyebab permasalahannya. Yaitu dengan cara berusaha menghentikan kemunculan anak di jalanan.

Keempat program strategi intervensi di atas kemudian lebih dikerucutkan lagi oleh Lusk menjadi tiga program strategi intervensi. Yang mana program strategi intervensi ini cukup dikembangkan di banyak rumah singgah sebagai model pendekatan dalam menangani anak jalanan. menurut Lusk yang dikutip oleh Sudrajat (1997:4), antara lain sebagai berikut:

\section{1) Street Based}

Merupakan penganan di jalan atau tempat-tempat anak jalanan berada, kemudian para street educator datang kepada mereka, berdialog, mendampingi mereka bekerja, memahami dan menerima situasinya serta menempatkan diri sebagai teman. Dalam beberapa jam, anak-anak diberikan materi pendidikan dan keterampilan, di samping itu anak jalanan memperoleh kehangatan hubungan dan perhatian yang bisa menumbuhkan kepercayaan satu sama lain yang berguna bagi pencapaian tujuan intervensi.

2) Centre Based

Pendekatan ini merupakan penanganan di lembaga atau panti. Anak-anak yang masuk dalam program ini di tampung dan diberikan pelayanan di lembaga atau panti seperti pada malam hari diberikan makanan dan perlindungan, serta perlakukan yang hangat dan bersahabat dari pekerja sosial. pada panti yang permanen disedikan pelayanan pendidikan, keterampilan, kebutuhan dasar, kesehatan, kesenian, dan pekerjaan. Dalam penanganan di lembaga atau di panti terdapat beberapa jenis atau model penampungan yang bersifat sementara (drop in centre) dan tetap (residential centre) untuk anak jalanan yang masih bolak balik ke jalan biasanya dimasukan ke dalam drop in centre, sedangkan untuk anak-anak yang sudah benar-benar meninggalkan jalanan akan di tempatkan di residential centre.

3) Community Based

Di dalam community based penanganan melibatkan seluruh potensi masyarakat, utamanya keluarga atau orang tua anak jalanan. Pendekatan ini bersifat preventif, yakni mencegah anak-anak turun ke jalan. Keluarga diberikan kegiatan penyuluhan pengasuhan anak dan peningkatan taraf hidup, sementara anak-anak diberi kesempatan 
memperoleh pendidikan formal maupun informal, pengisian waktu luang dan kegiatan lainnya. Pendekatan ini bertujuan meningkatkan kemampuan keluarga dan masyarakat agar sanggup melindungi, mengasuh dan memenuhi kebutuhan anak-anaknya.
Ketiga model ini adalah alternatif dari pendekatan penanganan anak jalanan. Jika ditelisik dari tipologinya, ketiga pendekatan tersebut memiliki fokus masing-masing, yaitu:

Tabel 1

Pendekatan dan Penanganan Anak Jalanan

\begin{tabular}{|l|l|l|}
\hline $\begin{array}{l}\text { Pengelompokan Anak } \\
\text { Jalanan }\end{array}$ & $\begin{array}{l}\text { Pendidikan } \\
\text { Program/Strategi }\end{array}$ & Fungsi Intervensi \\
\hline $\begin{array}{l}\text { Anak yang masih } \\
\text { berhubungan/tinggal } \\
\text { dengan orang tua }\end{array}$ & Community based & Preventif \\
\hline $\begin{array}{l}\text { Anak yang masih ada } \\
\text { hubungan dengan } \\
\text { keluarga tetapi jarang } \\
\text { berhubungan/tinggal } \\
\text { dengan orang tua }\end{array}$ & Street Based & \\
\hline $\begin{array}{l}\text { Anak tersisih/putus } \\
\text { hubungan Centre Based } \\
\text { keluarga/orang tua }\end{array}$ & & \\
\hline
\end{tabular}

Sumber: Yayasan Kesejahteraan Anak Indonesia

Pada kasus anak jalanan, model pendekatan dan penanganan yang dilakukan untuk anak jalanan binaan ialah centre based dengan fungsi intervensi rehabilitatif, yaitu berusaha melepaskan anak dari jalanan. Walaupun berfokus pada centre based, secara tidak langsung rumah singgah juga menggunakan pendekatan community based dan street based yang dapat dilihat dari program dan kegiatannya.

Model penanganan dan pemberdayaan anak jalanan sangat penting diperhatikan karena model penanganan anak jalanan disesuaikan menurut kondisi anak jalanan yang beragam. Model-model yang diterapkan untuk anak jalanan tidak lepas juga dari pengaruh visi dan misi lembaga. Tata Sudrajat dalam Mulandar (1996:156) menjelaskan secara umum terdapat dua tujuan dalam penanganan anak jalanan, yakni:

1) Melepaskan anak jalanan untuk dikembalikan kepada keluarga asli, keluarga pengganti, ataupun panti.

2) Penguatan anak di jalan dengan memberikan alternatif pekerjaan dan keterampilan.

Kedua tujuan tersebut tampak saling melengkapi, yakni memperkuat anak di jalan kemudian mencarikan peluang untuk mengembalikan anak kepada keluarganya. 


\section{Rumah Singgah}

Munajat (2001:60) menjelaskan rumah singgah merupakan perantara antara anak jalanan dengan pihak-pihak yang membantu mereka. Rumah singgah bertujuan membantu anak jalanan dalam mengatasi masalahmasalahnya dan menemukan alternatif untuk pemenuhan kebutuhan hidupnya. Dengan demikian rumah singgah bukan merupakan lembaga pelayanan sosial yang membantu menyelesaikan masalah, namun merupakan lembaga pelayanan sosial yang memberikan proses informal dengan suasana resosialisasi bagi anak jalanan terhadap sistem nilai dan norma yang berlaku di masyarakat. Direktorat Jenderal Bina Kesejahteraan Sosial Departemen Sosial sebagaimana dikutip oleh Krismiyarsi (2004) mendefinisikan rumah singgah sebagai berikut:

a) Anak jalanan boleh tinggal sementara untuk tujuan perlindungan, misalnya: karena tidak punya rumah, ancaman di jalan, ancaman/kekerasan dari orang tua dan lain-lain. Biasanya hal ini dihadapi anak yang hidup di jalanan dan tidak mempunyai tempat tinggal.

b) Pada saat tinggal sementara mereka memperoleh intervensi yang intensif dari pekerja sosial sehingga tidak tergantung terus kepada rumah singgah.

c) Anak jalanan datang sewaktu-waktu untuk bercakap-cakap, istirahat, bermain, mengikuti kegiatan dan lainlain

d) Rumah singgah tidak memperkenankan anak jalanan untuk tinggal selamanya.

e) Anak jalanan yang masih tinggal dengan orang tua atau saudaranya atau sudah mempunyai tempat tinggal tetap sendirian maupun berkelompok tidak diperkenankan menetap di rumah singgah, kecuali ada beberapa situasi yang bersifat darurat.

f) Anak jalanan yang sudah mempunyai tempat tinggal tetap merupakan kondisi yang lebih baik dibandingkan dengan mereka yang membutuhkan rumah singgah sebagai tempat tinggal sementara, seperti kelompok anak yang hidup di jalanan.

Melalui proses informal dalam resosialisasi anak jalanan terhadap sistem nilai dan norma yang berlaku di masyarakat, diharapkan mampu mencapai tujuan penyelanggaraan rumah singgah. Tujuan penyelenggaraan rumah singgah itu sendiri ada dua macam, yaitu tujuan umum dan khusus. Tujuan umumnya adalah membantu anak jalanan mengatasi masalah-masalahnya dan menemukan alternatif untuk pemenuhan kebutuhan hidupnya. Masih dalam sumber yang sama, Direktorat Jenderal Bina Kesejahteraan Sosial Departemen Sosial, mengatakan bahwa tujuan khusus rumah singgah adalah:

a) Membentuk kembali sikap dan perilaku anak yang sesuai dengan nilai dan norma yang berlaku di masyarakat

b) Mengupayakan anak-anak kembali ke rumah jika memungkinkan di panti dan lembaga pengganti lainnya jika diperlukan.

c) Memberikan berbagai alternatif pelayanan untuk pemenuhan kebutuhan anak

Adapun dalam mencapai tujuan tujuannya, rumah singgah memiliki tugas dan fungsi. Mengacu pada Departemen Sosial RI sebagaimana dikutip oleh Triyanti (2001:55) mengemukakan fungsi rumah singgah sebagai berikut:

1. Tempat pertemuan pekerja sosial dengan anak jalanan. Dalam fungsi ini, rumah singgah merupakan tempat bertemu antara pekerja sosial dengan anak jalanan untuk menciptakan 
persahabatan, assessment dan melakukan program kegiatan.

2. Pusat assessment dan rujukan Rumah singgah menjadi tempat assessment terhadap masalah dan kebutuhan anak jalanan serta melakukan rujukan pelayanan sosial bagi anak jalanan.

3. Fasilitator

Rumah singgah memiliki fungsi sebagai perantara anak jalanan dengan keluarga, panti, keluarga pengganti, dan lembaga lainnya. Anak jalanan diharapkan tidak terus-menerus bergantung pada rumah singgah, melainkan dapat memperoleh kehidupan yang lebih baik melalui proses yang dijalani.

4. Perlindungan

Rumah singgah dianggap sebagai tempat perlindungan anak dari kekerasan, penyimpangan seks dan bentuk-bentuk lain yang terjadi di jalanan.

5. Pusat informasi

Dalam fungsi ini, rumah singgah menyediakan informasi tentang berbagai hal yang berkaitan dengan kepentingan anak jalanan seperti data dan informasi tentang anak jalanan, bursa kerja, pendidikan, kursus keterampilan dan lain-lain

6. Kuratif-Rehabilitatif

Rumah singgah diharapkan mampu mengatasi permasalahan anak jalanan dan memperbaiki sikap dan perilaku sehari-hari yang akhirnya akan dapat menumbuhkan keberfungsian anak.

7. Akses terhadap pelayanan

Sebagai persinggahan, rumah singgah menyediakan akses kepada berbagai pelayanan sosial. pekerja sosial membantu anak mencapai pelayanan tersebut.

8. Resosialisasi

Lokasi rumah singgah berada di lingkungan masyarakat sebagai upaya mengenalkan kembali norma, situasi dan kehidupan bermasyarakat bagi anak jalanan. Dengan harapan adanya pengakuan, tujuan dan upaya dari warga masyarakat terhadap penanganan masalah anak.

Dari beragamnya kegiatan yang disediakan oleh rumah singgah, anak jalanan dapat memilih kegiatan mana yang ingin diikutinya. Semakin banyak kegiatan yang diikuti oleh anak jalanan di dalam rumah singgah sejatinya akan mengurangi intensitas mereka berada di jalanan. Selain itu, fungsi rumah singgah ini diharapkan meningkatkan keberfungsian sosial mereka baik jasmaniah maupun rohani.

\section{Prinsip Rumah Singgah}

Prinsip-prinsip rumah singgah yang dikemukakan Direktorat Bina Pelayanan Sosial Anak sebagaimana dikutip oleh Krismiyarsi (2009:40), yaitu:

1. Semi institusional

Anak jalanan sebagai penerima pelayanan boleh bebas keluar masuk baik untuk tinggal sementara maupun hanya untuk mengikuti kegiatan.

2. Terbuka 24 jam

Anak jalanan boleh datang kapan saja, siang hari maupun malam hari, terutama bagi anak jalanan yang baru mengenal rumah singgah. Anak jalanan yang sedang dibina atau dilatih datang pada jam yang telah ditentukan, misalnya paling malam pukul 22.00 waktu setempat. Hal ini memberikan kesempatan kepada anak jalanan untuk memperoleh perlindungan kapan pun. Para pekerja sosial siap dikondisikan untuk menerima anak dalam 24 jam tersebut, oleh karena itu harus ada pekerja sosial yang tinggal di rumah singgah.

3. Hubungan informal (kekeluargaan) Hubungan-hubungan yang terjadi di rumah singgah bersifat informal seperti perkawanan atau kekeluargaan. 
Anak jalanan dibimbing untuk merasa sebagai anggota keluarga besar di mana para pekerja sosial berperan sebagai teman, saudara atau orang tua. Hubungan ini membuat anak merasa diperlakukan seperti anak lainnya dalam sebuah keluarga dan merasa sejajar karena pekerja sosial menempatkan diri sebagai teman dan sahabat. Dengan cara ini diharapkan anak-anak mudah mengadukan keluhan, masalah, dan kesulitan sehingga memudahkan penanganan masalahnya.

4. Bebas terbatas untuk apa saja bagi anak

Anak dibebaskan untuk melakukan apa saja di rumah singgah seperti: tidur, bermain, bercanda, bercengkrama, mandi, dan sebagainya. Tetapi anak dilarang untuk perilaku yang negatif, seperti: perjudian, merokok, minuman, keras dan sejenisnya. Dengan cara ini diharapkan anak-anak betah dan terjaga dari pengaruh buruk. Peraturan dibuat dan disepakati oleh anak-anak.

5. Persinggahan dari jalanan ke rumah atau alternatif lain

Rumah singgah merupakan persinggahan anak jalanan dari situasi jalanan menuju situasi lain yang dipilih dan ditentukan oleh anak, misalnya kembali ke rumah, mengikuti saudara, masuk panti, kembali ke sekolah, alih kerja ke tempat lain, dan sebagainya.

6. Partisipasi kegiatan yang dilaksanakan di rumah singgah didasarkan pada prinsip partisispasi dan kebersamaan.

Pekerja sosial dan anak jalanan memahami masalah, merencanakan dan merumuskan kegiatan penanganan. Dengan cara ini anak dilatih belajar mengatasi masalahnya dan merasa memiliki atau memikirkan kegiatan-kegiatan yang dilaksanakan.

7. Belajar bermasyarakat

Anak jalanan seringkali menunjukkan sikap dan perilaku yang berbeda dengan norma masyarakat karena lamanya mereka tinggal di jalanan. Rumah singgah ditempatkan di tengah-tengah masyarakat agar mereka kembali belajar norma dan menunjukkan sikap dan perilaku yang berlaku dan diterima masyarakat

Rumah singgah adalah salah satu upaya pemberian pelayanan sosial yang mana diharapkan dapat digunakan semaksimal mungkin untuk anak jalanan. Dengan prinsip rumah singgah yang terbuka dan fleksibel, anak jalanan dapat mendapatkan perlindungan karena mereka biasa mengunjungi rumah singgah kapanpun. Dan rumah singgah adalah satu-satunya tempat yang dapat didatangi anak jalanan untuk bisa melakukan berbagai kegiatan yang bermanfaat dan mendapat perhatian dari staff rumah singgah.

Masalah anak jalanan merupakan masalah yang cukup kompleks. Secara ekonomis, mereka berada di jalan hanya untuk mencari makan. Secara sosial psikologis, mereka merupakan sebuah komunitas yang memiliki karakter tersendiri. Mekanisme pertahanan diri dalam suasana kebersamaan bisa menjadi pendorong munculnya keinginan hidup bebas tanpa tahu bahwa ada orang lain yang berbeda dengannya.

Adapun pendidikan dalam rumah singgah diharapkan mampu untuk memberikan wawasan terhadap anak-anak jalanan perempuan ini. Rumah singgah bisa membuat pelatihan. Pelatihan yang diselenggarakan menggunakan prinsip belajar pendidikan orang dewasa. Sebagaimana yang disebutkan oleh Knowles (1979), prinsip pendidikan orang dewasa antara lain:

1. Orang dewasa memiliki keinginan untuk belajar

2. Orang dewasa mau belajar jika ia merasa perlu 
3. Orang dewasa belajar sambil bekerja

4. Orang dewasa belajar dengan memecahkan masalah secara realistis

5. Orang dewasa merespon setiap metode yang bervariasi

Sebab menurut Saleh (2007) Pelatihan atau pembelajran yang menggunakan dan menerapkan metode pendidikan dewasa akan lebih mudah diterima oleh anak jalanan dibanding dengan pelatihan atau pembelajaran yang klasikal. Adapun prinsip pendidikan dalam pemberdayaan perempuan menurut Lilik (2009:12), antara lain:

1. Sikap rasional, kemampuan menilai situasinya sendiri

2. Partisipatoris interaktif, bersikap sabar

3. Artikulatif, mendapat pengakuan sosial

4. Bersahabat, menjunjung tinggi nilai sosial dan solidaritas

Dari prinsip pemberdayaan perempuan ini, Lilik juga menulis tentang indikator keberhasilan pogram pendidikan pemberdayaan perempuan, meliputi:

1. Terlaksananya pendidikan perempuan berbasis potensi lokal secara kreatif, efisien, efektif, inovatif, dan produktif.

2. Meningkatnya pemahaman tentang potensi lokal di wilayahnya

3. Meningkatnya kecakapan hidup (pengetahuan, sikap, keterampilan, dan perilaku) perempuan sesuai dengan potensi lokal yang dikembangkan.

4. Meningkatnya kepercayaan diri pada perempuan untuk terlibat dalam perencanaan, pelaksanaan pendidikan perempuan berbasis potensi lokal.

5. Meningkatnya ekonomi perempuan dan keluarga.

Pendekatan centre-based menyertakan penyuluhan sebagai proses perubahan perilaku yang akan menyangkut aspek pengetahuan, keterampilan dan sikap mental, sehingga sasaran dalam hal ini adalah anak jalanan perempuan dan keluarga anak jalanan perempuan.

Artikel ini lebih lanjut akan mencoba membangun sebuah model pemberdayaan anak jalanan. Sebuah model mungkin belum akan berarti banyak, namun kehadirannya, setidaknya akan menambahkan jumlah pemikiran/gagasan terkait upaya pemberdayaan anak jalanan.

\section{PEMBAHASAN}

Upaya pengentasan anak jalanan, memiliki tiga model pendekatan. Street based, Centre Based, dan Community Based. Centre based adalah salah satu upaya pendekatan dan penanganan terhadap anak jalanan. Realisasi centre based ialah dalam bentuk rumah singgah. Suatu pendekatan yang diterapkan lembaga dalam menjangkau anak jalanan melalui pengadaan program dan pelayanan dengan cara pemberian dukungan pada kesejahteraan dan perkembangan anak ketika mereka berada jauh dari keluarga mereka. Konsep ini digunakan secara bergantian oleh 
sebuah kelompok yang mengacu pada tempat penampungan sementara atau drop in centre yang juga menyediakan pelayanan menetap atau residential centre bagi anak jalanan yang terlantar.

Program ini dibuat untuk anak jalanan yang sudah teralineasi dengan kehidupan mereka, jauh dari rumah dan sudah memutuskan hubungan dengan keluarga. Tetapi, pada kasus tertentu, sesuai dengan fungsinya yaiu rehabilitatif, pendekatan centre-based kerap digunakan rumah singgah untuk membantu anak jalanan mengurangi waktunya di jalanan dan menghabiskan waktunya di rumah singgah untuk kegiatan bermanfaat. Seorang pekerja sosial ditempatkan di centre based guna mendampingi anak untuk membangkitkan kesadarannya kembali tentang kehidupan yang harus dijalaninya dan mengingatkan akan keluarganya.

\section{Centre based approach}

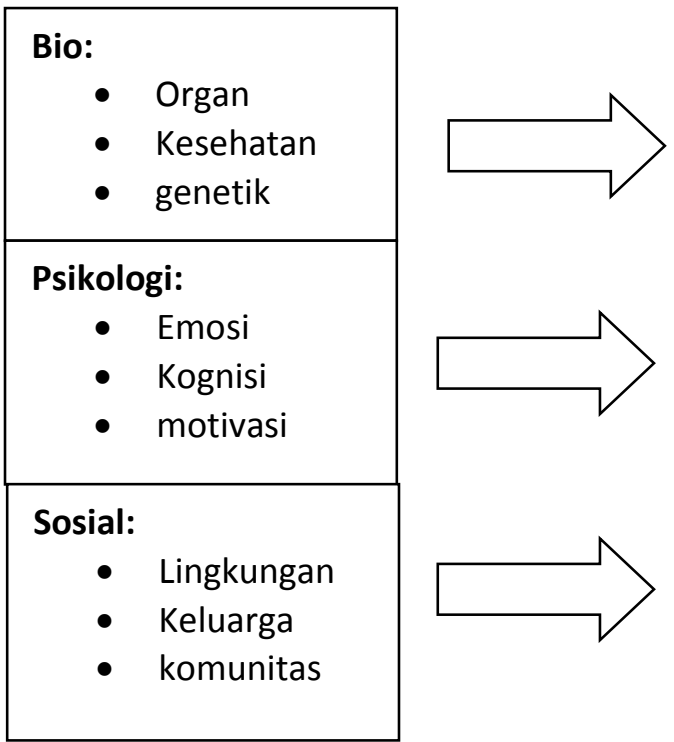

Bekerja sama dengan pihak kesehatan memberikan pengetahuan mengenai kesahetan dan pendidikan seks dini.

Melakukan pendampingan edukasional, fasilitatif, representatif, dan teknis

Melakukan resosialisasi terhadap lingkungan baru;

Melakukan pemberdayaan untuk anak jalanan dan pemberdayaan untuk orang tua anak jalanan berupa keterampilan
Assessmen biopsikososial adalah konsep yang dikembangkan dalam rumah singgah khusus anak jalanan perempuan. Assessmen ini digunakan dalam pelaksanaan rehabilitasi sosial untuk memecahkan permasalahan yang dihadapi anak jalanan. Pada aspek fisik mengkaji keadaan fisik (seputar kesehatan) yang bermasalah kemudian diberikan terapi untuk penyembuhannya. Aspek psikologis mengkaji keadaan jiwa yang dialami anak jalanan. Aspek sosial mengkaji speutar relasi dengan individu, keluarga, dan masyarakat.
Pada pendekatan centre based anak diajarkan untuk kembali berorientasi pada nilai dan norma yang berlaku di masyarkat. Menurut Childhope Asia Philiphines, program centre based terbagi menjadi 2 tahap, yaitu tahap drop-in shelter sebagai tahap awal di mana anak masih diperbolehkan bolak balik ke jalan karena anak masih beradaptasi dari lingkungan jalan ke lingkungan rumah. Kemudian dilanjtkan dengan tahap residential shelter di mana anak tinggal menetap dan hidup di tempat tersebut sebagai rumah tinggal mereka dengan aturan-aturan rumah yang dibuat untuk merehabilitasi mereka 
supaya tidak lagi kembali ke jalan. Perlakuan serta pemahaman khusus dibutuhkan bagi para petugas atau pendamping di rumah singgah. Pasalnya, di rumah singgah khusus perempuan ini nantinya anak-anak akan diberikan pemahaman mengenai gender, fungsi keluarga, fungsi reproduksi, dan pendidikan seks dini sebagai bekal mereka ke depan.

Adapun peran LSM atau rumah singgah yang memiliki petugas, mereka memiliki tugas sebagai pendukung dan pendamping bagi anak-anak jalanan dalam kehidupan mereka sehari-hari, sehingga anak dapat berkembang ke arah yang positif dan lebih berkualitas untuk kehidupan mereka selanjutnya di masa depan. karena program centre based erat kaitannya dengan rumah singgah, program tersebut memiliki acuan dalam melayani anak jalanan. Peneliti merencanakan alur dalam melayani anak jalanan perempuan.

Penjangkauan dan pendampingan di jalan, kegiatan kunjungan keluar rumah singgah untuk menjangkau anak jalanan sebagai upaya menciptakan kontak pendahuluan dan persahabatan dengan mereka; Identifikasi anak, kegiatan ini merupakan suatu proses untuk menginventarisasikan dan mengkaji identitas anak, riwayat hidup, masalah, kebutuhan, potensi dan dinamika kehidupan anak jalanan secara cermat dan teliti; Resosialisasi, kegiatan mengenalkan sikap dan perilaku anak agar sesuai dengan nilai dan norma sosial; Pemberdayaan untuk anak jalanan, dimaksudkan sebagai upaya mengangkat anak jalanan dari keterlantaran serta sekaligus mengatasi masalah-masalah yang disandangnya dengan berusaha memenuhi segala keperluan yang dibutuhkan, terutama yang menyangkut kebutuhan dasar hidupnya, ditambah lagi dengan mengajarkan keterampilan, serta memberikan wawasan mengenai wanita, gender, pendidikan seks dini, dan fungsi reproduksi; Pemberdayaan untuk orang tua anak jalanan, merupakan upaya rumah singgah dalam rangka membangun kembali fungsi-fungsi sosial keluarga melalui bimbingan sosial, bimbingan kewirausahaan maupun pendampingan; Terminasi, Serangkaian kegiatan yang dilakukan pada akhir sebuah proses pemberdayaan anak jalanan. Kegiatan terminasi dilaksanakan dengan maksud agar hasil-hasil yang telah dicapai pada tahap proses pemberdayaan bisa dipertahankan dan secara terus menerus dapat ditumbuh kembangkan. 


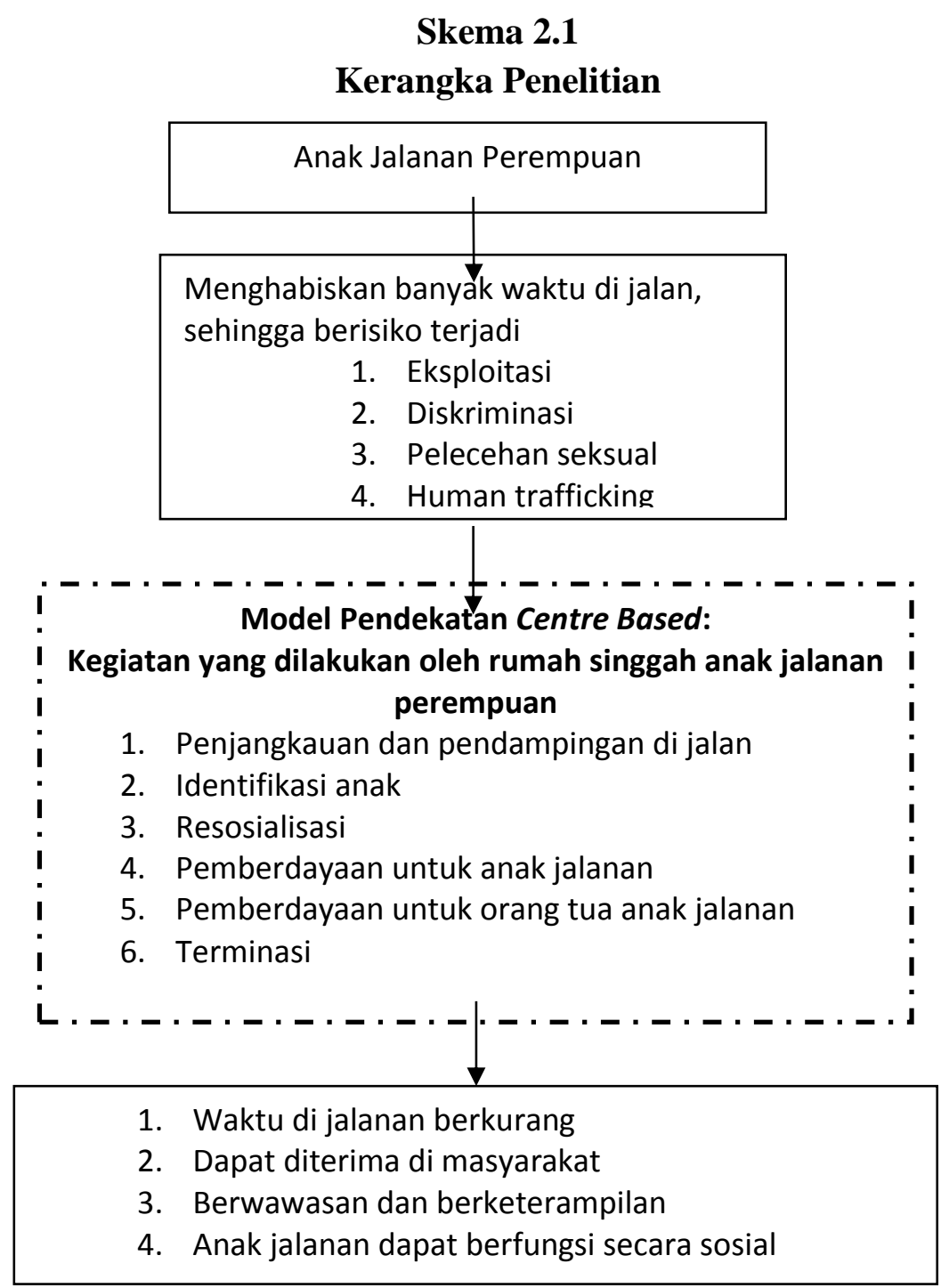

\section{KESIMPULAN}

Sebagai tindak lanjut dari ide rumah singgah anak jalanan perempuan ini, kerja advokasi lain dalam pengembangan budaya hukum yang baik bagi masyarakat pun juga dilakukan. Dengan melakukan sosialisasi dan kampanye di beberapa kelurahan dan kecamatan dengan mengajak kerja sama organisasi-organisasi yang ada akan memperkecil potensi anak jalan perempuan terintimidasi. Paling tidak di sudut manapun di kota besar bila terjadi gejala anak jalanan perempuan yang mengalami kekerasan dan eksploitasi seksual maka masyarakat dan aparat sendiri mampu menjalankan peran dalam memberikan perlindungan khusus untuk mereka.

Di rumah singgah anak jalanan perempuan ini, mereka diajarkan juga pendidikan tentang seks, fungsi keluarga, dan hal-hal lain yang terkait dengan kehidupan sebagai perempuan. Diharapkan dari adanya rumah singgah anak jalanan perempuan ini, mereka mengerti tentang pentingnya memahami dan menjaga diri. Lebih jauh lagi, mereka memutuskan untuk tidak kembali lagi turun ke jalan. 
Ke depan, kesadaran publik dan negara dalam menjalankan peran perlindungan khusus bagi anak jalanan perempuan perlu ditingkatkan, tidak sekadar mencegah anak menjadi korban namun termasuk mereduksi risiko lainnya selama anak-anak perempuan terlanjur menjadi anak jalanan. Ruang aman dan peluang pendidikan serta ekonomi juga perlu dibuka bagi mereka sehingga secara otomatis akan mengurangi jam-jam mereka berada di jalanan.

\section{Daftar Pustaka}

Andari, Soetji, dkk. 2007. Uji Coba Model Perlindungan Anak Jalanan terhadap Tindak Kekerasan. Yogyakarta: B2P3KS.

Amal, Bakhrul Khair. 2003. Pemberdayaan Anak Jalanan Melalui Rumah Singgah: Studi Kebijakan Penanganan Anak Jalanan di Indonesia. Tesis. Depok: Universitas Indonesia

Armai, Arief. 20002. Rumah Singgah Sebagai Tempat Alternative Pemberdayaan Anak Jalanan. (Jurnal Fajar) Jakarta: LPM UIN. hal. 1

Direktorat Kesejahteraan Anak, Keluarga, dan Lanjut Usia - Deputi Bidang Peningkatan Kesejahteraan Sosial. 2000. Modul Pelatihan Pimpinan Rumah Singgah. Jakarta: Badan Kesejahteraan Sosial Nasional.
Departemen Sosial RI. 2003. Upaya Pencarian Model yang Efektif dalam Penanganan Anak Jalanan. (Penelitian Universitas Muhammadiyah Jakarta bekerja sama dengan Balitbangsos Departemen Sosial RI)

Johanes, Fery. 1997. Penanganan Anak Jalanan di Indonesia. Bandung: STKS

Odi Shalahuddin. 2000. Anak Jalanan Perempuan. Semarang: Yayasan Setara

Pietrzak, J., Ramler, M., Renner, T., \& Gilbert, N. 1990. Practical program evaluation: Examples from child abuse prevention. London: Sage Publications.

Pincus A., Manahan A. 1973. Social Work Practice: Model \& Method. Itasca, IL: F. E. Peacock Publishers.

Sudrajat, A. 1989. Profil Anak Jalanan di DKI Jakarta. Jakarta: Badan Penelitian dan Pengembangan Sosial. Departemen Sosial RI.

Sudrajat, Tata. 1997. Mengenali Program Penanganan Anak Jalanan, Makalah untuk pelatihan Beranting Pendamping Anak. YKAI

Wahyu Nurhajdatmo. 1999. Seksualitas Anak Jalanan. Yogyakarta: Pusat Penelitian Kependudukan UGM. 